\title{
Prisca sapientia v renesančním platonismu
}

\author{
Daniel Špelda
}

Abstract:

The article deals with the ideas about history of knowledge, which were widespread in the Renaissance period, especially between representatives of Platonism. The Renaissance platonists did not understand the history of knowledge as a continuous progress, but were convinced of the existence of ancient wisdom (prisca sapientia), to be restored.

V osvícenských historiích vědy se nezřídka vyskytoval motiv konstantní distribuce geniality $v$ dějinách. ${ }^{i}$ Př́roda propůjčuje každé době a každé kultuře stejné množství geniálních lidí. Skutečnost, že nynější věk, notre siècle de lumière, je nadřazený předchozím obdobím, není způsobena vyšším výskytem géniů, ale tím, že uběhlo dostatečné množství času, během něhož se nashromáždila pozorování, provedly se experimenty, nasbíraly se zkušenosti a také se podařilo předat a rozvinout výsledky teoretické práce předchozích badatelů.i Osvícenští historikové tuto myšlenku občas dokládali na př́kladu Isaaca Newtona. Cambridgeský fyzik byl podle nich bezesporu geniální, ale také se narodil ve správnou dobu a za správných

\footnotetext{
i Článek byl vypracován s laskavou podporou GA ČR, číslo projektu P401/12/0129. ii Turgot 1913, t. I, s. 117; Bailly 1777, s. 212; Perrault 1693, t. I, s. 60.
} 
okolností. Kdyby žil ve vzdálenější minulosti nebo na březích Orinoka, nedokázal by vytvořit pravdivý systém světa založený na univerzálním zákonu prítažlivosti. 'To, co dělí Newtona od prvních pozorovatelů oblohy, není míra rozumnosti, ale nezměrné množství času. ${ }^{i i}$

Osvícenství do svého výkladu dějin vědění již samozřejmě zahrnovalo myšlenku, že kvalita poznání bytostně závisí na množství uplynulého času. Spolehlivé a pravdivé poznání prírody si vyžaduje dostatečně dlouhou dobu. Tato myšlenka se začala objevovat již ve filosofii a vědě 17 . století a někdy se vyjadřovala působivou metaforou: veritas filia temporis. Toto rčení pochází z Gelliových Noctes Atticae (XII,11,7), ale v souvislosti s pokrokem vědění ho asi poprvé začal užívat Francis Bacon.iii Moderní evropská kultura přetavila myšlenku o závislosti poznání na čase do ideje vědeckého pokroku a častokrát si nepřipouští, že po větší část dějin evropského myšlení platila zcela jiná představa o vztahu mezi poznáním a časem.

Tématem této studie je přistup $\mathrm{k}$ dějinám vědění, který předcházel vzniku myšlenky pokroku. Jde o ideál prastaré moudrosti (prisca sapientia), který byl rozšířený $v$ renesančním myšlení. Vzhledem $\mathrm{k}$ tomu, že není možné zahrnout do jediné studie celou renesanci, soustředí se další výklad na nejvýznamnější zastánce ideálu prisca sapientia - na renesanční platoniky. I když se jedná jen o několik autorů, Ize vzhledem $k$ jejich významu a vlivu konstatovat, že jejich myšlenky podávají dostatečně srozumitelné svědectví o tom, jak výrazně se renesanční pohled na dějiny vědění lišil od moderního.

i Gren 1799, s. 195; Laplace 1884, s. 455; Bailly 1785, t. III, s. 573 n., s. 580. ii Bailly 1781, s. iv.

iii Bacon 1963, vol, I, s. 458. K dějinám metafory viz Saxl 1963; Panofsky 1962; Gentile 1920; Zittel 2002, Hadot 2010, Blumenberg 1986. 
Představa o kontinuálním pokroku poznání není pro evropské myšlení přirozená, ale představuje spíše vynucený důsledek obecnějších změn v chápání smyslu a rozsahu lidského vědění, $k$ nimž došlo na přelomu renesance a novověku. Tyto změny jsou skicovitě naznačeny $v$ posledním oddíle této studie.

Renesanční humanisté do určité míry přehodnotili dosavadní náhled na dějiny poznání. Tradičně se v křestáanském prostředí soudilo, že pohanská kultura byla uvězněná $v$ temnotách náboženského bludařství až do doby, kdy Kristus přinesl na svět světlo pravdy. Petrarca a po něm další humanisté starou metaforu temného věku změnili tím, že ji vztáhli i na nenáboženské vědomosti a spojili ji s historickým obdobím po pádu římské říše. Pohanská antika považovaná ve středověku za temnou dobu vlády pohanství se pro humanisty stala věkem světla, který by měl být obnoven. Proti tomu jako tenebrae začal být označován středověk symbolizovaný scholastickou vzdělaností. Za důsledky středověkého barbarství považovali humanisté první poloviny 15 . století velké schisma, spory mezi „papalisty“ a „konciliaristy“ i neúspěšný ekumenický koncil ve Ferraře a Florencii. Symbolem rozpadu a také civilizačního neúspěchu barbarského středověku se pro humanisty stalo dobytí Konstantinopole. Rozklad stávajícího světa, který si humanisté palčivě uvědomovali, mělo napravit renovatio celé

i Viz klasický článek Mommsen 1942; srov. též Findlen 2002. 
kultury v podobě znovuoživení. Jediná naděje pro barbarskou a zkaženou kulturu podle humanistů spočívala v obratu do vzdálené minulosti, kde se v temnotách historického zapomnění nacházely nejzazší kořeny moudrosti poskytující fons veritatis. Pravda tedy není, jako pro novověké myslitele, dcerou času, ale nachází se na jeho počátku a je na něm nezávislá. Pro renesanční autory neexistuje př́má úměra mezi uplynulým časem a kvalitou poznání. Pravda totiž byla zpř́stupněna člověku na počátku dějin ve své úplnosti. $V$ renesanční době se jí zvláště mezi platoniky začalo ríkat prisca sapientia nebo také prisca theologia. Později pak vatikánský knihovník Agostino Steuco s důrazem na nadčasovost prvotní pravdy zavedl výraz philosophia perennis. ${ }^{\prime}$

Renesanční doba měla $\mathrm{k}$ dispozici $v$ zásadě tři hlavní modely dějin vědění. ${ }^{i} \mathrm{~V}$ helénistické době a $v$ pozdní antice bylo do značné míry rozšířeno aristotelské pojetí dějin vědění, které do značné míry převzala $\mathrm{i}$ scholastika.iii Podle této představy bylo na počátku vědění hrubé a nejasné, často se mísilo s poezií a mýtem, ale během času se postupně zdokonalovalo tím, že se stávalo systematičtějším, metodicky přísnějším a vědečtějším. Později církevní otcové, zvláště Eusébios z Kaisareje,

i Ebert 1929,1930; Dannefeldt 1952; Schmitt 1966; Schmidt-Biggemann 2004, Nejeschleba 2008, s. 98-105. Není jasné, zda renesanční autoři mezi těmito pojmy dělali rozdíly; je možné, že výrazem prisca sapientia se myslela spíše prŕrodní filosofie, která se týkala prírodního světa, zatímco pojem prisca theologia se vztahoval $\mathrm{k}$ náboženskému vědění. Součástí staré moudrosti ovšem měly být i prapůvodní zákony určující správný chod obce; otázkou tedy zůstává, zda zákony patří spíše k sapientia či theologia. Kromě toho je třeba uvážit, že jedním z podstatných cílů úsilí renesančních platoniků bylo sjednocení světské moudrosti a kněžské teologie.

ii Hankins ${ }^{2} 1991$, s. 233 n.

iii Edelstein 1967, s. 105-132; Dodds 1973, s. 10-43; Zhmud 2006, s. 120-147. 
představili další koncepci, podle níž řečtí filosofové během svých návštěv v Egyptě ukradli nauky starozákonních proroků, především Mojžíšových, a vydávali je za své. Bůh tuto „egyptskou kořist“ připustil jen kvůli tomu, že chtěl připravit řecký svět na křestanství prostřednictvím filosofie, podobně jako připravil Židy prostřednictvím starozákonních proroků. Po příchodu Krista sice přestala být pohanská moudrost potřebná, nicméně židovský Starý zákon i nauky pohanských filosofů je možné dál využívat při výchově mládeže. Podobně jako mladé lidstvo i mladé křestáany by pohanští filosofové mohli připravit na slávu a pravdu Nového zákona, pokud byly jejich spisy očištěny od nebezpečných a zavádějících myšlenek. ${ }^{i} A$ konečně, z pozdního novoplatonismu vzešla představa o prastaré a polozapomenuté moudrosti, která je starší než řecká filosofie, křest'anství i židovství a pochází z Východu. ii Tato filosoficko-náboženská moudrost se předává potajmu mezi zasvěcenými a není přístupná obyčejným lidem, kteří na ni nejsou připraveni. Křestáanští platonikové pak trvali na tom, že dávná moudrost měla připravit pohany na světlo křestáanství, podobně jako Židé byli připraveni Mojžíšem.

Dokladem pro existenci pradávné moudrosti měly být domněle staré texty, o nichž dnes díky filologickým analýzám víme, že pocházejí z pozdní antiky. Renesanční učenci se ovšem domnívali, že tyto texty pocházejí z dávné minulosti lidského rodu a obsahují stř́pky pravdy, již první zákonodárci a mudrci získali božským vnuknutím. Mezi staré mudrce patřily tyto historické postavy, z nichž některé po sobě zanechaly spisy: Adam, Enoch, Abrahám, Noe, Zoroaster (Chaldejské věštby), Mojžíš (Pentateuch), Hermés Trismegistos (Asklépios, Poimandrés a další hermetika), král David, Orfeus

\footnotetext{
i Havrda 2009, s. 34; srov. Chadwick 1966, repr. 2002.

ii Burns 2006, s. 166; Hanegraaff 2009, s. 34.
} 


\section{AIOIIP 7./2013}

(orfické hymny), Pýthagorás a jeho žáci, Platón se svými dialogy, Sibylly (Sibylliny věštby), novoplatonikové, Dionýsios Areopagita, indičtí bráhmani a keltští druidové. $U$ různých renesančních autorů najdeme výčty starých mudrců, které se $v$ detailech lišily, ale $v$ zásadě panovala shoda, že první mudrcové byli inspirováni Bohem a předznamenali křestanství, zatímco pozdější, zvláště rečtí filosofové, převzali od egyptských kněží nauku Mojžíšovu.

Ale jaká byla vlastně motivace pro obrat do minulosti, $k$ domněle dávným textům? Co renesanční myslitele vedlo k pohledu zpět? A co si od něj slibovali? Na tyto otázky existuje zdánlivě jednoduchá odpověd': renesanční filosofové se domnívali, že vědění jejich doby je nedostatečné, nedokonalé a zkažené. Jestliže je zkažené vědění, je zkažená i společnost a kultura. Obnova prastarého, čistého a pravdivého vědění pak měla přinést nejen zdokonalení stávajícího vědění, ale měla také vést $k$ ctnostnému vedení života a $\mathrm{k}$ napravení společenských poměrů. $\mathrm{V}$ souvislosti s prisca sapientia Ize tedy hovořit o tom, že existoval ideál vědění, které mělo být obnoveno. Dále existovala diagnóza současného stavu vědění, která zdůvodňovala potřebnost návratu ke staré moudrosti. A konečně, existovala naděje, která se s obnovením prisca sapientia pojila. Ve všech těchto rysech vystupují určité svébytné aspekty renesančního chápání souvislosti mezi věděním a časem, které jsou námětem následujících kapitol. Výklad začíná vysvětlením diagnózy a naděje, protože právě na jejich základě se zformoval ideál vědění, které mělo přinést nápravu.

i Walker 1972, s. 20 n. et passim; Hanegraaff 2006; Stuckrad 2010, s. 25-31. 
V roce 1438 přicestoval na koncil do Ferrary byzantský císař a ve skupině jeho poradců se nacházel i osmdesátiletý stařec Georgios Gemistos (asi 1360-1452), který na koncilu na počest svého filosofického vzoru přijal jméno Pléthón. Pléthón zastával nepř́liš ortodoxní náboženská stanoviska a interpreti se dodnes přou o to, zdali zůstal křestanem, nebo zda chtěl oživit řecký polyteismus jako filosofické, racionální náboženství, které mělo přispět $k$ záchraně řecké identity před tureckou hrozbou i zhoubným vlivem latinského Západu. i

Je dobře doloženo, že Pléthón se intenzivně zajímal o sociální a politické problémy své doby a své země. Byl aktivní v byzantské státní správě, byl členem senátu, radil císařưm (a dostávalo se mu za to uznání v podobě nemalých odměn), navrhoval přestavbu státního aparátu, reformu ekonomiky i změnu armádního velení.ii Není tedy divu, že i Pléthónovo filosofické úsilí mělo sociálně-politickou motivaci. Pléthón svou filosofií chtěl přispět $k$ obnově skomírající byzantské říše a $k$ její záchraně před Turky. Domníval se, že ve své filosofii obnovuje dávnou moudrost prvního mudrce, jehož nauky se alespoň zčásti písemně dochovaly. Tímto mudrcem byl Zoroaster a za texty, v nichž se uchovala jeho moudrost, Pléthón považoval Chaldejské věštby. Ty mají původ v pozdním platonismu, ale

i Viz blíže Hladký 2010; Blum 2010, s. 95-108; Hoffmann 2007, s. 51-76; Garin 2008, vol. I, s. 221-224.

ii Woodhouse 1986, s. $87 \mathrm{nn}$. 
Pléthón jejich autorství přisuzoval právě Zoroasterovi. ${ }^{i} T e x t$ věšteb Pléthón doplnil vysvětlujícími komentáři, $v$ nichž se praví, že nauky, které se zde nacházejí, jsou společné zoroastriánům, pýthagorejcům, platonikům a dalším mudrcům. A s odvoláním na Plútarcha zde také tvrdí, že Zoroaster žil pět tisíc let před trojskou válkou a tehdy sepsal své nauky. ${ }^{\text {"i }}$

Ve svém hlavním filosofickém díle Zákony chtěl Pléthón představit takové uspořádání institucí vobci, které by řídilo životy lidí v souladu $s$ jejich prirozeností a které by poskytlo naplnění jejich přirozené touze po blaženosti. Podle Pléthona právě Zoroasterova moudrost obsahovala návod k nejlepšímu státnímu uspořádání i autentickou představu o lidském štěstí. Tato moudrost spočivala na několika základních principech, které byly po Zoroasterovi dále uchovávány, předávány anebo realizovány jeho žáky a následovníky. Největším z nich byl Platón, kterého do Zoroasterovy nauky zasvětili pýthagorejci. Jejich učitel totiž studoval zoroastrismus během svého pobytu mezi mágy $\vee$ Asii.iii Platónský zoroastrismus pak podle Pléthóna obsahuje nejvhodnější principy pro ustanovení staronového státního zřízení, jež by nebylo postiženo novotami, které způsobily úpadek byzantské řiše. Ohrožení barbary je totiž důsledkem špatné politické

i Autentický zoroastrismus Pléthón neznal, viz Woodhouse 1986, s. 26, srov. Nejeschleba 2004.

ii Pléthon 1995, s. 19-22, 35; srov. Pléthón 1858, s. 252-253; srov. Plútarchos, De Iside et Osiride, $369 \mathrm{~d}$. B. Tambrunová pomocí důvtipné analýzy různých chronologických údajů dokazuje, že zatímco Byzantinci standardně kladli počátek světa do doby 5508/5509 před Kristem, datoval Pléthón Zoroasterův život do doby 674 let před tím, než křest’anský Bůh stvořil svět, viz Tambrun 2006, s. 84 n. Kriticky se k některým analýzám Tambrunové staví V. Hladký 2009.

iii Pléthón 1858, s. 257, srov. Hladký 2010, s. 33. 
organizace (kakopolítea) a záchrana celé říše i její kultury závisí na rychlé změně státního uspořádání.

Zdá se, že Pléthón za jednoho z hlavních viníků úpadku řecké civilizace považoval církev - její nauku, obřady, ale také třeba nečinný život mnichů v klášterech. Naděje pro Řeky spočívá v návratu ke státnické, filosofické a teologické moudrosti, která je starší než byzantská církev. Očistný návrat ke kořenům se snaží Pléthón zdůraznit také tradiční ideou kosmopolis. Mezi věcmi na zemi a na nebi existuje analogie a souvislost. .i Politický svět lidí by měl napodobovat společnost bohů, státní uspořádání by mělo sledovat teologický systém. Kvůli tomu Pléthón $v$ Zákonech představuje propracovanou hierarchii řeckých božstev, která se měla stát vzorem pro uspořádání byzantské řiše i všech ostatních států a která měla zajistit jejich mírové soužití.iii Podle Pléthóna není však zkažená jen řecká církev, ale v různé míre všechna náboženství. Náboženský život celého lidstva tedy potřebuje nápravu a obnovu, jež měla vzejít z návratu $\mathrm{k}$ principům, které lidé obdrželi na počátku času.

III

I když byl Pléthónův vliv v Itálii jen omezený, myšlenka kulturní nápravy prostřednictvím oživení a uplatnění platónské filosofie se stala jedním z hlavních témat renesančního platonismu. ${ }^{\text {iv }}$ Najdeme je již ve Ficinově raném

\footnotetext{
i Hladký 2010, s. 7 n.; srov. Blum 2011.

ii Pléthón 1858, III,15, s. 104.

iii Tambrun 2006, s. 117-124, srov. tamtéž, s. 197 nn.

iv Hankins ${ }^{2}$ 1991, s. 208.
} 
spisu De christiana religione.' Ficino zde uvádí, že na počátku dějin existovalo prastaré náboženství (prisca religio), do něhož patří všechna pohanská předkřestáanská náboženství. Toto „přirozené“ náboženství vyvolal Bůh nepřímým způsobem. Vložil totiž do lidí přirozenou touhu po náboženství, díky níž lidé objevili již $v$ raných dobách některá božská mystéria. Bůh totiž prastarým mudrcům neprímo a $v$ tajuplné podobě ukázal některá svá tajemství. V tomto věku prvotního náboženství existovala jednota mezi filosofií a náboženstvím. U všech národů byli stejní lidé knězi i filosofy. Jako př́klady uvádí Ficino hebrejské proroky, perské mágy, indické bráhmany, egyptské matematiky a metafyziky, etiopské gymnosofisty, řecké orfiky a pýthagorejce, galské druidy a první rímské krále. "i Mezi těmito dávnými lidmi (apud priscorum) bylo náboženství všeobecně rozšířené, protože božská prožretelnost nedovolí, aby nějaká doba či nějaká oblast světa zcela postrádala náboženství - i když Bůh připustil mnoho různých podob uctívání. iii Dobu prvotního náboženství Ficino $v$ jednom dopisu (př́značně nazvaném Philosophia et religio germanae sunt) považuje za zlatý věk svaté filosofie, kterou se snaží jako oddaný následovník antiky napodobit. ${ }^{i v}$ Filosof může být označen za

i Vynikající rozbor poskytuje Edelheit, 2008, s. 205-270.

ii Ficino 1596, s. 1. „...iidem apud omnes gentes philosophi, et sacerdotes existerent".

iii Ficino 1596, s. 4. „Idcirco divina providentia non permittit esse aliquo in tempore, ulla mundi regionem omnis prorsus religionis expertem, quamvis permittat variis locis atque temporibus, ritus adorantis varios observari.“

iv Ficino 1596, s. 854. „Quorsum haec de sapientiae pietatisque copula? Ut videlicet meminerimus primo quantum aureis illis sacrae Philosophiae seculis debeamus. Deinde (ut ipse intelligas) qua ratione Marsilius sectator antiquitatis, non solum in uno illo religionis libro ... verum etiam in omnibus eius scriptis una cum philosophicis semper religiosa, pro ingenii facultate, coniugat.“ 
moudrého a zbožného jen tehdy, pokud nás pozvedává ke nazírání Boha (ad contemplationem Dei) a současně v nás zapaluje lásku k božskému dobru. ${ }^{i}$

Tradiční součásti prisca sapientia jako orfika, hermetika, chaldejské a Sibylliny věštby jsou pro Ficina projevem předkřestanské a nenaplněné přirozené lidské touhy po božském. Tato touha se naplňuje až v křestanství. Křestanství sice představuje pokračování tradice prastaré teologie, ale zásadně ji překonává, protože se opírá o prímý zásah Boha do lidských dějin: zázraky, zjevení a Vtělení. Bůh se stal člověkem, aby předal lidstvu dokonalé a pravé náboženství. Věčné a pravé náboženství sestoupilo z nebes do pozemských dějin a slovo se stalo tělem (verbum ipsum naturam assumpsit humanam). ${ }^{\text {ii }}$ Před Vtělením dal Bůh lidstvu pouze touhu po božském, která se projevovala různým způsobem v rozličných kultech. Vtělením však lidé získali prostředek kdosažení Boha, ke sjednocení s Bohem. Bůh se stal člověkem, aby ukázal lidstvu, že i člověk se může svým způsobem stát Bohem. Kristus tak poprvé $v$ dějinách lidského rodu představil naději, jak uspokojit přirozený pud po dosažení božského, po vzestupu k Bohu.iii Křestáanství završuje předchozí řadu nepřímých zjevení, inspirací a osvícení, jichž se dostalo starým mudrcům. Ve virtuální, skryté, alegorické, ne zcela uvědomované podobě však bylo v dějinách přítomné od počátku, protože je to jediné pravé náboženství.

Vzhledem k tomu, že prapůvodní náboženství bylo nepřímo podníceno a inspirováno Bohem, je podle Ficina přirozené, že prisci theologi dokázali

i Ficino 1596, s. 854.

ii Ficino 1596, s. 20.

iii Ficino 1596, s. 20: „Cur olim Deus homo factus est, ut homo quandoque quodammodo Deus efficeretur. Deus enim quodammodo fieri potest, qui naturali instinctu cupit, studetque esse divinus.“ 
předjímat příchod a podobu náboženství dokonalého a pravého. Křestanské představy jediného Boha, jeho Syna a celé Trojice jsou věčné, protože Bůh je nepř́mo a v náznaku odhalil již předkřestanským mudrcům. Pradávná zbožná filosofie nakonec pro Ficina není ničím jiným než učeným náboženstvím: tota Priscorum Philosophia nihil est aliud quam docta religio.' Tím je zajištěna teologická bezúhonnost předkřestanských autorů, protože i v nich promlouvá Bůh.

Mezi nimi náleží klíčové místo Platónovi, $v$ jehož filosofii jsou zastoupeni všichni staří mudrcové. Zdá se dokonce, že pro Ficina jednotliví prisci theologi představují pouze dílčí fáze $v$ uskutečňování všezahrnující Platónovy filosofie, která představuje završení a uzavření pohanské tradice předané pravdy. "i Platonismus představoval alternativní teologii darovanou Bohem Řekům jako pohanský protějšek Starého zákona. Také Platón podle Ficina předznamenává a ohlašuje príchod Krista a jeho pravdy. Na počátku

i Ficino 1596, s. 854.

ii „Mezi filosofy byl (sc. Hermés Trismegistos - D. Š.) první, kdo se od témat fyzikálních a matematických prikiklonil $\mathrm{k}$ nazírání věcí božských, a byl rovněž první, kdo velemoudře rozmlouval o Boží svrchovanosti, pořádku daimonů a proměnách duší. Proto byl zván autorem první teologie: jej následoval Orfeus, který obdržel druhé místo v dávné teologii (antiquae theologiae). Po Aglaofémovi nastoupil v teologii Pýthagorás, jenž byl zasvěcen do obřadů Orfeových, a po něm přišel Filoláos, učitel našeho božského Platóna. Takto se z podivuhodné řady šesti teologů vynořila jedna navzájem ve všem souladná škola dávné teologie (una priscae theologiae undique sibi consona secta), jejíž počátky pocházejí od Herma a jež dosáhla naprosté dokonalosti v božském Platónovi.“ Ficino 1596, s. 1836; český překlad Chlup 2007, s. 12. Tuto posloupnost s výjimkou Herma Trismegista Ficino nejspiše převzal z Prokla, který v Platónské teologii $(\mathrm{I}, 5)$ rovněž uvádí, že veškerá řecká teologie pochází od Orfea. S orfickými naukami později Aglaofémos seznámil Pýthagoru a ze spisů orfiků a pýthagorejců později prostřednictvím Filoláa čerpal Platón. Viz Proklos 1968, s. 24-26. 
Platónské teologie Ficino uvádí, že skutečná filosofie je zbožná filosofie, a proto v sobě spojuje poznání i uctívání Boha. Tuto podmínku splňuje právě Platónova filosofie, která vede ad contemplationem cultumque dei. Stojí vůči křestáanskému zjevení jako Měsíc ke Slunci. Ficino touto metaforou chce naznačit, že platónské myšlení ve své úplnosti může být uchopeno teprve prostřednictvím světla křestanské pravdy. ' Novoplatonikové tedy podle Ficina ke svým výkladům Platóna užívali křestáanské moudrosti, kterou čerpali z Jana, Pavla a Dionýsia Areopagity. Již Platón podle Ficina ve svých listech (pravděpodobně Ep. 6) naznačoval, že dávná tajemství budou po mnoha staletích lidem odhalena. A to se vskutku stalo $v$ době Núménia a Filóna, protože inned po působení apoštolů a rozšíření jejich spisů začali platonikové užívat božské světlo křestanů kvýkladu božského Platóna (divino enim Christianorum lumine usi sunt Platonici ad divinum Platonem interpretandum), a dokázali tak poprvé úplně pochopit myšlenky dávných teologů. Podle Ficina je zřejmé, že Núméniova, Filónova, Plotínova, Jamblichova a Proklova mystéria jsou převzatá od evangelistů. Všechno, co novoplatonikové řekli o božské mysli, andělích a jiných teologických záležitostech, si zjevně přivlastnili od evangelistů (manifeste ab illis usurpaverunt).i Novoplatonismus tak představuje nejhlubší a nejautentičtější podobu zbožné filosofie.iii

$S$ novoplatoniky končí podle Ficina jedna důležitá část dějin vědění. $V$ nich se střídají období rozkvětu, kdy jsou filosofie a náboženství úzce spojeny, s

i Ficino 2001-2006, sv. I, s. 8.

ii Ficino 1596, s. 25. V jednom z dopisů Ficino uvádí, že novoplatonikové od křest’anských mudrců převzali také myšlenku trojice, která se pak objevuje v jejich výkladech Platóna, který sám o Trojici výslovně nehovoří (Ficino 1596, s. 956). iii Edelheit 2008, s. 233 n. 
obdobími zkaženosti, během nichž se náboženství mění v pověry a bludy. $V$ lidských dějinách nejprve existovalo období původního vnuknutí, které skončilo Platónem mezi pohany a proroky mezi Židy. Po nich následoval úpadek, který se projevoval jako nadvláda pověr a bludů. Úpadkové období skončilo príchodem Krista, který opět dokázal sjednotit filosofickou moudrost a náboženství a naučil to i své učedníky, zvláště Pavla, Jana a Dionýsia Areopagitu. Po Dionýsiovi ovšem následoval opět úpadek (calamitas Ecclesiae), který se podařilo na čas zahnat novoplatonikům, již začali číst Dionýsia. ${ }^{.}$Proklem však končí linie staré moudrosti, která přes Platóna sahala až k Hermovi a Zoroasterovi do doby před Trojskou válkou. $\checkmark$ dalších dějinách evropské kultury se dochovaly jen nedokonalé střípky této tradice."

Podobně jako pohanská filosofie ani křestáanství nemělo v dalších dějinách štastný osud. Ficino je přesvědčen, že vopravdové podobě křestanství existovalo jen $v$ apoštolské církvi. Kristus, apoštolové a jejich žáci představují nejdokonalejší způsob uctívání Boha.iii Díky nim a jejich svědectví o zázracích křestáanství zvítězilo v celém západním světě. Ale toto vítězství také vedlo $\mathrm{k}$ jeho rostoucí profanaci. Hned na první straně De christiana religione Ficino lká nad štastnými dobami rané církve, kdy existovalo božské spojení moudrosti a náboženství (divinam hanc

i Ficino 1596, s. 925: „Platonicos ... legisse Dionyssii libros antequam nescio qua calamitate Ecclesiae delitescerent..." Srov. Hankins ${ }^{2}$ 1991, s. 284 n.

ii Tyto stř́pky původní pohanské moudrosti Ficino vyjmenovává v dopise Martinu Uraniovi a řadí mezi ně kromě novoplatoniků Macrobia, Augustini multa, Boëtii consolatio, Chalcidiův komentár k Platónovi, Michaela Psella, Avicebrona, AlFarábího dílo De causis, Jindřicha z Gentu, Avicennu, Dunse Scota, Bessariona a quaedam speculationes kardinála Kusánského; Ficino 1596, s. 899.

iii Ficino 1596, s. 5 n. 
sapientiae, religionisque copulam). Pak následovala saecula infelicia, kdy došlo k oddělení moudrosti a náboženství, kdy lidé znevážili nejposvátnější a nejcennější pravdy, které stejně pochopili špatně, a prováděli rituály, jimž nerozumějí. Jak dlouho ještě, ptá se Ficino, budeme snášet neštastný a ubohý osud tohoto železného věku ?' V něm se náboženství změnilo v pouhý habitus. " Z křestanské víry se vytratila hloubka a upřímná víra. Místo nich nastoupila povrchní zbožnost ze zvyku a prázdné obřady, které se vyznačují nezbožnou nádhernou a pověrčivostí.iii

Železný věk, v němž došlo k rozchodu filosofické moudrosti a náboženství, se pro Ficina vyznačuje dvěma hlavními rysy: za prvé, víra se $v$ něm bez pomoci filosofie zvrhla $v$ zaslepenou pověru a hloupé bludařství. Díky tomu víru opouštějí nejvzdělanější lidé a kulturní elity propadají bezbožnosti. ${ }^{i v} \mathrm{Za}$ druhé, západní latinský svět se přiklonil k Aristotelově filosofii, která přinejmenším v některých svých odnožích vede $\mathrm{k}$ bezbožnosti. Ficino má zvláště na mysli alexandristy, podle nichž je rozum smrtelný, a averroisty, kteří tvrdí, že existuje jeden společný rozum pro všechny lidi, a proto neexistuje individuální nesmrtelnost. Obě školy podle Ficina dále škodí víře tím, že popírají vládu prozřetelnosti nad lidmi a jejich dějinami. ${ }^{v}$ Aristotelismus obecně je pak pro Ficina jen suché rozumování bez směřování k Bohu, které je tak důležité v platónském myšlení. Autoritářská scholastika zase vychovává bezbožné učence, kteří podléhají iluzi, že

i Ficino 1596, s. 1. „Quamdium duram et miserabilem hanc ferrei seculi sortem sustinebimus?" Srov. též Ficino 1596, s. 854.

ii Ficino 1596, s. 7 n.

iii Ficino 1596, s. 1134, 1386, 1402, 1508, 1510, 1516, 1520. Na tato místa upozorn̆uje Hankins ${ }^{2} 1991$, s. 181.

iv Ficino 1596, s. 3.

v Ficino 1596, s. 1537, srov. Ficino 1596, s. 628; srov. též Edelheit 2008, s. 255. 


\section{AIOIIP 7./2013}

rozumějí božským věcem kvưli tomu, že dokáží podle pravidel logiky nakládat s výroky autorit. ${ }^{i}$ Aristotelsky orientovaná scholastická teologie by tedy ve jménu všeobecného očištění měla být nahrazena platónsky založenou teologií, v níž by mělo dojít ke sjednocení starodávné, předkřestáanské, ale Bohem inspirované moudrosti se zjeveným náboženstvím.

U Ficina na jedné straně nacházíme pléthónskou vizi dějin, podle níž je náboženské vědění opakovaně poškozováno hloupými a omezenými představiteli církve. Na straně druhé je tu i eusébiovský motiv, podle něhož Kristovo zjevení odhaluje skrytý význam a smysl mystérií zjevených Židům a pohanským filosofům. Náboženství i filosofie však podléhají procesům rozkladu, který se projevuje především jako nárůst bezbožnosti. Ficino spatřuje naději ve spojení křestáanství a platonismu, který se nyní rozhodla Prozřetelnost obnovit jeho prostřednictvím. Platonismus představuje dokonalé ztělesnění moudrosti a křestanství zase dokonalou podobu náboženství. jejich spojení má napodobit zlatý věk, kdy filosofie a náboženství byly v jednotě. Dávná pia philosophia se má stát východiskem a základem pro vytvoření docta religio. $\mathrm{V}$ tomto spásném procesu si sám Ficino přisuzoval nezanedbatelnou roli. Lékař Ficino byl vyvolen Prozřetelností, aby vyléčil duše vzdělaných Florentanů, podobně jako to $v$ Athénách udělal Platón, medicus animorum. iii Ficino se totiž nejspíše domníval, že platónská filosofie a kontemplativní způsob života s ní spojený přivede florentské městské elity zpět k opravdové, zvnitřnělé zbožnosti, která se však bude opírat i o rozumový náhled a přestane být pouhou

i Ficino 1596, s. 1532.

ii Hankins ${ }^{2} 1991$, vol. I, s. 285.

iii Ficino 1596, s. 871. 
pověrou. Díky učenému náboženství a za přispění Boží milosti pak bude možné vytvořit spravedlivou a ctnostnou společnost, která se přestane zmítat v politických svárech. Platónská filosofie tradičně formující vztah mezi tělem a duší se měla stát také pojítkem mezi duchovní sférou společnosti a její reálnou politikou.

Pico della Mirandola se s Ficinem shodoval v tom, že filosofie se nachází v úpadku. Podle Pika se totiž rozšírilo zhoubné přesvědčení, že zkoumání prríčin věcí, přírody nebo Boha nemá smysl, pokud neposkytuje výhody nebo nezaručí zisk. Za moudré dokonce, stěžuje si Pico, jsou „považováni jen ti, kdo zlásky k moudrosti dělají zboží“.i O soudobých filosofech pak prohlašuje jednoznačně: „Celý jejich život je totiž zasvěcen honbě za ziskem nebo uspokojování vlastní ctižádosti, a proto si nijak necení poznání pravdy pro ně samo. “iii

Jediná naděje pro filosofii, která ztratila kontemplativní samoúčelnost, spočívá podle Pika v návratu k prapůvodní jednotě, kterou představuje priscorum theologia. Mezi její představitele patři Mojžíš, „jenž není příliš vzdálen od vydatného pramene posvátného a nevýslovného poznání, jehož nektarem se opájejí andělé". iv Mojžíšovi v prastarých dobách bylo předáno dávné vědění, kterým se nyní mohou sytit jen andělé. $K$ dávné moudrosti Pico dále řadí kabalu, Pýthagoru a "chaldejské spisy“, jimiž patrně myslí Chaldejské věštby. ${ }^{\vee}$ Mezi prisci theologi, kteří pěstovali matematický způsob filosofování, Pico počítá, nejspíše podle Proklova vzoru, Pýthagoru,

i Ficino 1596, s. 294-296.

ii Mirandola 2005, s. 85.

iii Mirandola 2005, s. 85.

iv Mirandola 2005, s. 73.

v Mirandola 2005, s. 79-81. 
Aglaoféma, Filoláa, Platóna a rané platoniky. Jejich matematická nauka se „nedbalostí potomků“ ztratila téměř beze stopy, Pico však prohlašuje, že ji po mnoha probdělých nocích znovuobjevil. ${ }^{i} \mathrm{~A}$ konečně, Pico raadí k prisca theologia Herma Trismegista, "Zoroastera, Homéra a Orfea. iii

Podobně jako Ficino i Pico usiloval o znovuobnovení prastaré theologie. Philosophia nova, kterou Pico ohlašuje v Oratio de hominis dignitate ${ }^{\text {iv }}$ a kterou má zastupovat druhá část devíti set conclusiones (tj. teze s čísly 500900), je ve skutečnosti philosophia renovata, jak upozorňuje moderní vydavatel tezí S. A. Farmer. Číslo 500 bylo podle Farmera v kabalistické numerologii symbolem návratu a opakování. Počet pěti set tezí „podle vlastního mínění“ má symbolicky vyjádřit, že „nový“ Pikův systém je ve skutečnosti návratem $k$ původní filosofické jednotě, která se v průběhu dějin rozpadla. ${ }^{v}$ Koneckonců hned pětistá teze říká, že neexistuje přírodní ani božská otázka, $v$ niž by se Aristotelés a Platón neshodovali. ${ }^{\text {vi }}$

Zatímco Ficino obnovením prisca sapientia myslel především návrat $\mathrm{k}$ Platónově filosofii (kterou ovšem zaměňoval $s$ novoplatonismem),

i Mirandola 2005, s. 99-101. Téměř stejnými slovy Pico v Apologii říká, že matematický způsob filosofování zavedli prisci Theologi, zvláště Pýthagoras, Aglaofémos, Filoláos a Platón, ale nedbalostí potomků se vytratil, ut vix vestigia ipsius ulla reperiamur; Mirandola 1969, sv. I, s. 120.

ii Mirandola 2005, s. 96; srov. Mirandola 1969, s. 119; srov. název hermetických tezí: Conclusiones secundum priscam doctrinam Mercurii Trismegisti Aegypti, in Farmer 1998, s. 340-342.

iii Mirandola 2005, s. 112-114, téměř shodně Apologia, viz Mirandola 1969, s. 124. iv Zmíněná např. Mirandola 2005, s. 98.

v Farmer 1998, s. 32, 550.

vi Mirandola, 900 conclusiones, in: Farmer 1998, s. 365: „Nullum est quaesitum naturale aut divinum in quo Aristoteles et Plato sensu et re non conveniant, quamvis verbis dissentire videantur.“ 
Mirandola uvažoval jinak. Tato odlišnost je způsobena především Pikovým konkordistickým programem, podle něhož všechny filosofie v zásadě tvoří jednotu. Podle Pika dějiny vědění poskytují především svědectví o tom, že všechny filosofické školy v zásadě pocházejí ze stejného zdroje, který představuje prisca theologia. Všechny proudy filosofického myšlení v sobě obsahují zrnka prapůvodní pravdy, a proto v sobě skrývají možnost ke sjednocení do jediné pravdivé a definitivní filosofie. Všechny školy, jejichž teze Pico představuje vhistorické části conclusiones, měly společný pradávný původ, a proto také určitý podíl na univerzální, nadčasové pravdě. Př́stup $k$ této pravdě pak není umožněn zpětným sledováním nepřerušovaného předávání moudrosti mezi zasvěcenými, jak se domníval Ficino. Mirandola spíše než historicky uvažuje hermeneuticky: v názorech mnoha filosofů a škol je nutné odhalit a vysledovat prapůvodní jiskry pravdy obalené během věků nánosem nepravd, alegorií a omylů. $\mathrm{K}$ tomu má pomoci univerzální metoda výkladu, jíž se má stát kabala a symbolicky pochopená matematika. I když rozličnost stylů a názorů znamenala podle Pika pro filosofii př́nos, vedla různorodost současně $k$ překrytí prvotní pravdy, a tak s sebou přinesla i zoufalství a nemožnost dosáhnout pravdy. Podle Pika nyní nastal čas, kdy má být znovusjednocena filosofická různorodost a odstraněn každý svár. Za růzností filosofických stanovisek se skrývá jednota, kterou je třeba odhalit v textech. Společný počátek předcházející všechny velké filosofické školy tedy pro Pika není bodem, $\mathrm{k}$ němuž bychom se vraceli. Představuje spíše záruku pro možnost konečného sjednocení, pro uspořádání souboru pravdivých tezí načerpaných z pozorné četby filosofických spisů. 'Pico se nejspíše domníval, že plánovaná rímská disputace o devíti stech tezích má být prvním krokem při nastolení

\footnotetext{
i Malusa 1993, s. 31.
} 
filosofického smíru a odkrývání pravé, jediné a definitivní filosofické pravdy.'

IV.

Ideální vědění, $k$ němuž by se lidstvo mělo vrátit, se $v$ pojetí renesančních platoniků vyznačovalo několika rysy, které lze přiblížit v několika bodech.

a) Prvním znakem prastarého vědění byla jeho esoteričnost. Předpokládalo se, že v korpusu (domněle) dávných textů není pravda jasně a srozumitelně vyložená, ale je uschována $v$ náznacích, alegoriích a hádankách, jejichž výklad si vyžaduje velký interpretační um. Takový postoj plynul z obecného přesvědčení, že původní jednoduchá a jasná pravda se během staletí přejímání, předávání a překládání zatemnila kvůli neschopnosti nebo neobratnosti jejích uchovavatelů. Kromě toho se za myšlenkou esoteričnosti dávné pravdy skrývaly další filosofické motivy. Především pýthagorejský ideál vědění, které není určeno všem. Nejvznešenější pravdy nejsou určené prostému lidu, ale musí být ukryty za závojem alegorií, mýtů, hádanek a náznaků. Kromě pýthagorejců se $v$ tomto ohledu renesanční autoři odvolávali i na Platóna, který ve druhém Listu píše, že o Jednom se smí mluvit jen $v$ hádankách. Podle další autority, Klementa Alexandrijského, se i jeden z nejstarších dávných mudrců, Mojžišs, vyjadřoval v jinotajích, které si ovšem řečtí filosofové ne vždy vyložili správně." Biblickým potvrzením

i Farmer 1998, s. 46.

ii Klement Alexandrijský 2009, V,I,10, s. 134 n.; srov. tamtéž V,4,19-26; s. 153165. 
představy tajného vědění dále bylo Matoušovo „Neházejte perly před svině, nebo je nohama zašlapou, otočí se a roztrhají vás" (Mt 7:6). Dalším klasickým zdůvodněním pro ukrývání pravdy před prostým lidem bylo zabití Sókrata athénskou demokracií. Vulgus není ani připraven, ani vybaven na úplné přijetí pravdy a její nevhodné prozrazení by mohlo ohrozit samotné její uchovavatele, tj. filosofy. Toto přesvědčení Ize najít u Pléthóna, podle něhož dávné Zoroasterovo vědění není určeno pro každého. Pléthón má pochybnosti o tom, zda poznání nejvyšších věcí, které bylo předáno zákonodárcům a filosofům, dokáží všichni lidé unést, nebot' mnozí mají slabou a omylnou povahu. ${ }^{i}$ Kardinál Bessarion ve své obhajobě platonismu piše, že o nejvyšších věcech psal Platón jen prostřednictvím tajemství, hádanek a tajuplných obrazů a po vzoru pýthagorejců a Chaldejců je nechtěl sdělovat prostým lidem. ii Podobně jako Pýthagoras, staří filosofové a druidové i Platón svěřil své tajné učení, které se nehodí pro dav a prosté lidi, toliko několika zasvěceným. iii Ficino zase uvádí, že staří teologové měli odedávna ve zvyku božská tajemství zakrývat čísly, matematickými symboly anebo básnickými obrazy. iv Podobně Pico della Mirandola píše v Heptaplu, že Mojžíš se ve svých knihách vyjadřuje hrubě, a ne jako filosof či teolog. Je to však jen projev chvályhodného zvyku starých mudrců nepsat o božských věcech zcela srozumitelně, aby nebyly přístupné prostému lidu. ${ }^{\vee}$

i Pléthón 1858, I,2, s. 28.

ii Bessarion 1927, s. 10-14.

iii Bessarion 1927, s. 19. Srov. Martin 2000.

iv Ficino 1596, s. 871: „Vetus autem Theologorum mos erat divina mysteria tum Mathematicis numeris, \& figuris, tum Poëticis figmentis obtegere." Srov. podobně Ficino 1596, s. 386.

v Mirandola 1942, s. 172-174. 
Právě Pico asi také představu tajnosnubné tradice rozpracoval nejvíce. Obecně podle něj platí, že staří mudrcové se o božských záležitostech vyjadřovali nejasně nebo skrytě. ${ }^{i} \mathrm{Na}$ počátku dějin vědění stojí Mojžíš, kterému se dostalo podílu na božském vědění. Nezjevil však na př́íkaz Boha prostým lidem pravdu v její plnosti, ale nechal ji předávat ve skryté ústní tradici: „...Mojžíš na hoře nepřijal od Boha pouze zákon, který pak sepsal v pěti knihách a zanechal potomkům, ale rovněž tajnější a pravý výklad tohoto zákona. Bůh mu však přikázal, aby sice zákon uvedl ve známost mezi lidem, ale jeho výklad nesvěřoval knihám ani jej veřejně nerozhlásil - měl jej pouze odhalit Jozuovi, synu Núnovu, aby jej ten pod prísným závazkem mlčení zase předal dalším, po řadě nastupujícím velekněžím. “ii Toto tajné vědění, které se smělo sdělovat pouze dokonalým (perfectis), se předávalo ústně, sine litteris, a tajně z generace na generaci. Je zachyceno v kabale, kterou Pico charakterizuje jako ineffabilis theologia a fons sapientiae. iii Sklon k tajnosnubnosti připisuje všem prvním mudrcům, včetně Orfea. Jak bylo zvykem u dávných teologů (veterum mos theologorum), uvádí se v Oratio, i Orfeus zahalil své tajné nauky do tajemných příběhů a básnických podobenství, které neměly být všeobecně přístupné. Proto také Pico hrdě zpravuje o tom, „jakou námahu a jaké obtíže obnášelo to, že jsem z klamné spleti hádanek a z temnoty přiběhů vynesl na světlo skrytý obsah tajné filosofie“. iv $V$ jednom dopise Ficinovi z roku 1486 zase Pico píše o tom, že se mu Božím řízením dostaly do rukou „věštby máků Ezry, Zoroastra a

i Mirandola 1942, s. 172: „... fuisse veterum sapientium celebre institutum res divinas ut, aut plane non scriberent, aut scriberent dissimulanter."

ii Mirandola 2005, s. 107; obdobně Mirandola 1969, s. 175. Viz podrobněji Black 2006, s. 95-147.

iii Mirandola 2005, s. 108-111; zcela stejně Mirandola 1969, s. 123.

iv Mirandola 2005, s. 115; téměř stejně Mirandola 1969, s. 124. 
Melchiara, v nichž se Ize dočíst v úplné a neporušené podobě i to, co se u Řeků čte v podobě zkomolené či kusé“. ${ }^{i} V$ kabalistických tezích pak Pico připisuje zahalování pravdy před nepovolanými zraky i Aristotelovi. Ten podle něj dál utajil pomocí spekulací a verbální stručnosti božskou filosofii, kterou již dávní filosofové ukryli svými př́běhy. ${ }^{i i}$

b) Dalším rysem ideálního vědění je jeho božský původ. Původní pravdu daroval Bůh prvním mudrcům prostřednictvím nepřímých zjevení v podobě osvícení nebo inspirace. Kristus pak přinesl na zem boží pravdu v její čistotě a úplnosti. Pléthón ve svých Zákonech uvádí, že bohové lidem darovali poznání, které má vést lidi k pochopení podstaty bohů.iii Božství chce, aby bylo poznáno, proto také do nás zaselo semena své racionality. Plethónův žák Bessarion zase uvádí, že Platónovo učení nejenže čerpá z židovských proroků, ale dokonce se opírá o boží zjevení. Vkontextu diskuse o nesmrtelnosti duše Bessarion dokonce říká, že ve Faidru Sókratés mluví, jako by byl prodchnut božstvím (quodam numine afflatus). ${ }^{\text {iv }}$ Podobně $\mathrm{i}$ Ficino se domnívá, že prapůvodní náboženství bylo nepřímo podníceno a inspirováno Bohem. Proto také prisci theologi dokázali předjímat příchod a podobu náboženství dokonalého a pravého. Orfeus, Platón, Hermés i Zoroaster hovoři ve svých naukách o božím synu za pomoci Boží (adiuvante

i Cit. dle Mirandola 2005, s. 62, pozn. 22, srov. Farmer 1998, s. 486-487. ii Pico, Conclusiones cabalisticae XI,63, in: Farmer 1969, s. 546: „Sicut Aristoteles diviniorem philosophiam, quam philosophi antiqui sub fabulis et apologis velarunt, ipse sub philosophicae speculationis facie dissimulavit et verborum brevitate obscuravit.“

iii Pléthón 1858, I,3, s. 42, srov. Hladký 2010, s. 44. Tambrunová upozorňuje na místa $\mathrm{v}$ antické literatuře uvádějící motiv daru poznání od bohů, na která mohl Pléthón vědomě narážet; viz Tambrun 2006, s. 86.

iv Bessarion 1927, s. 153. 
Deo). ' Podle Pika della Mirandola zase Bůh předal pravdu prvnímu ze starých mudrců, Mojžíšovi. ii

c) Ideální vědění se dále vyznačuje tím, že je univerzální. Pléthón ve svém výkladu genealogie moudrosti upozorňuje, že Zoroaster není nejstarší zákonodárce lidstva, ale nejstarší mudrc, jehož jméno a nauky se dochovaly. Existovali tedy i jiní mudrcové před Zoroasterem a po něm. Podle Pléthóna dokonce Zoroaster ani není objevitelem svého učení. To je spíše odrazem archetypálního, věčného světa idejí, a proto je i stejně věčné. Ve svém komentáři k Chaldejským věštbám uvádí, že věčný intelekt, stvořitel duše, vsadil do lidských duší obrazy inteligibilních forem, díky nimž se člověk může vymanit z tělesnosti a pochopit pravé bytí.iii Také v Zákonech Pléthón píše, že základní principy dávné moudrosti jsou věčné stejně jako nebe a vždy byly př́tomné mezi lidmi, nebot' byly vsazeny do lidských duší. Řídili se jimi všichni staři mudrcové, dnes ovšem známe jen jejich výklad od Zoroastera. $^{i v} \mathrm{~V}$ minulosti tedy existovala jediná univerzální moudrost rozšířená mezi všemi lidmi, která byla zformulována a vyjádřena mnoha způsoby. Dochovaly se pouze Zoroasterovy myšlenky v Chaldejských věštbách.

Jestliže byl obraz inteligibilního světa vložen do duší všech lidí jako prostředek $\mathrm{k}$ jejich osvobození z materiálního světa, musel být univerzální $\mathrm{i}$ $v$ časovém a zeměpisném ohledu. Univerzálnost vědění v čase či v dějinách

i Ficino 1596, s. 19. Srov. tamtéž, s. 12: „Adventus Christi tanquam divinus ab initio mundi praedictus a Prophetis, Sybillisque fuit, non in Astrologia peritis, sed divinitus inspiratis.“

ii Mirandola 1942, s. 170.

iii Oracles chaldaïques 1995, ad oracle 27,28.

iv Pléthón 1858, III,43, s. 252. 
zajištuje u Pléthóna cyklické pojetí času. Byzantský filosof věřil ve stoickou ideu osudu a věčného návratu. Všechny události, které mají nastat, jsou od věčnosti ustanoveny v nejlepším pořádku Diem, nejvyšším pánem všeho. ${ }^{i}$ $\checkmark$ časném světě, který je jen odrazem světa idejí, se nemůže odehrát nic vskutku nového. Životy a skutky lidí se opakují, nepřichází nic nového a vše se jednou zase zopakuje. ii Novost je jen příznakem nepřítomnosti vzorové ideje. Obrazy idejí, zaseté do lidských duší, nezávisí na čase, stačí je oživit. Skutečný mudrc se tedy nikdy neodchyluje od prastarých názorů, které jsou pravdivé, a vždy zvítězí nad omyly. Proti tomu neprátelé skutečné moudrosti, které Pléthón označuje jako sofisty, stále zavádějí novoty. Proto také Plethón sám o sobě ř́ká, že pouze opakuje prastarou moudrost, aniž by usiloval o jakékoli vylepšení.iii

Pokud jde o geografickou univerzalitu, podle Pléthóna není Zoroasterova nauka jen nejstarší, ale také se vyskytuje $v$ různých obměnách po celém světě. K Zoroasterovým principům měly blízko zákony některých starověkých národů, které však nikdy nebyly dokonalé. Patřily mezi ně zákony Indů na východě a Iberů na západě v době, kdy žil Zoroaster. Zákonodárce Iberů neznáme, říká Pléthón, zákonodárcem Indů byl Dionýsios nebo Bakchus. ${ }^{i v}$ Podle B. Tambrunové tímto př́kladem Pléthón dává najevo rozšířenost prapůvodní nauky po celé oikumeně, která se ve starověku vymezovala právě Iberským poloostrovem na západě a Indií na východě. ${ }^{*}$ Prastará univerzální moudrost, která je odrazem inteligibilního

i Pléthón 1858, II,6, s. 66.

ii Pléthón 1858, III,43, s. 256.

iii Pléthón 1858, I,2, s. 32-34; k sofistům viz I,2, s. 28; srov. III, 32, s. 130.

iv Pléthón 1858, III,43, s. 252.

v Tambrun 2006, s. 107. 
světa, se může snadno rozšírit po celé zemi - a zachránit pozemský svět před úplnou zkázou.

Západní platonici se $v$ otázce univerzality dávného vědění mnohem více soustředili na téma, které pro ně a legitimitu jejich úsilí bylo klíčové slučitelnost prisca sapientia s křestáanskou teologií. Pravda musí být univerzální, a proto se musí shodovat nauka dávných proroků i křestanství. Proto se Ficino různými způsoby snažil prokázat, že celá filosofie starých mudrců není nic jiného než docta religio. Užívá k tomu několik prostředků. Jedním z nich je tradiční platónský ideál kněze-filosofa. Zoroasterova filosofie podle Ficina nebyla ničím jiným než moudrá zbožnost a uctívání boha (sapiens pietas cultusque divinus). Hermovy rozpravy vždy začínaly modlitbami a končily obětinami. Stejně tak Orfeova a Aglaofémova filosofie se cele zabývaly chválou božského. Pýthagoras začínal své studium filosofie ranním zpěvem posvátných hymnů a Platón začínal vždy u Boha. 'Disciplina Priscorum není ani tak filosofie jako spíše Filothea. ${ }^{\text {ii }}$

Dalším dokladem univerzality staré moudrosti jsou Ficinovy opakované poukazy na to, že dávní teologové spolu souhlasí a že jejich učení je ve shodě s křestanskou naukou. Mezi tyto shody patří napríklad odmítání materiální podstaty duše. iii Jinde zase Ficino píše, že v otázce vztahu těla a duše spolu souhlasí (consentiunt) Mojžíš, Zoroaster, Hermés a Platón. ${ }^{\text {iv }}$ Kvůli tomu, aby doložil podíl prastaré filosofie, tj. platonismu, na pravdě, uchyluje se i Ficino k představě „egyptské kořisti“. Platón totiž měl podle něj

i Ficino 2001-2006, XII,1, vol. IV, s. 24. Ke vztahu pia philosophia a prisca sapientia viz Euler 1996, s. 210-228.

ii Ficino 1596, s. 854.

iii Ficino 2001-2006, VI, 1, vol. II, s. 124-126.

iv Ficino 2001-2006, X,3, vol. III, s. 138. 
bezesporu nejbliže k Mojšišově učení, což dokládá Numéniův citát, podle něhož Platón byl Mojžíšem, který mluví attickým jazykem. ' V Platónových spisech je pak obsažena celá prisca gentilium theologia, v níž se shodovali (consenserunt) Zoroaster, Hermés, Orfeus, Aglaofémus a Pýthagoras. ii

I u Ficina má univerzalita prastaré moudrosti geografický rozměr. Ficino se v pozdějších spisech, po roce 1469 , přiklonil ke genealogii mudrců, v podobě posloupnosti Zoroaster, Hermés, Orfeus, Agloafémus, Pýthagoras a Platón. Těchto šest mudrců kromě jiného reprezentuje tři tehdy známé kontinenty: Asii, Afriku a Evropu. J. Hankins upozorňuje na to, že v pozadí tohoto výčtu může být již zmíněné Ficinovo přesvědčení, že božská prozřetelnost nemohla připustit, aby nějaká část světa postrádala náboženství, a prostřednictvím „globálního“ rozšíření původní filosoficko-náboženské moudrosti je tato univerzální př́tomnost náboženství zajištěna. iii

Pro Pika della Mirandola je univerzálnost prisca sapientia garantována především společným původem. Nejstarším mudrcem byl Mojžíš. Egyptský Hermés, nejvyšší kněz a král, byl současníkem Mojžíše a přejal jeho názory. Egyptáné se později stali učiteli Řeků. Božská pýthagorejská filosofie vycházela z Mojžíšových nauk, kterým se Pýthagoras naučil v Egyptě. Podobně i Démokritos, Empedoklés a Platón se vzdělali $v$ Egyptě $v$ Mojžíšově moudrosti. Nejdůstojnějším pokračovatelem Mojžíše se stal

i Ficino 1596, s. 866: „...nihil aliud esse Platonem, quam alterum Mosem Attica lingua loquentem.“

ii Ficino 1596, s. 25.

iii Hankins ${ }^{2} 1991$, vol. II, s. 464. 
Platón. I Mirandola se v tomto ohledu odvolává na Núméniova slova, podle nichž Platón mluví jako samotný Mojžíš, jen řecky.'

Mojžíšova nauka nejenže byla první a inspirovaná Bohem, byla také všezahrnující. V úvodu ke svému Heptaplu Pico uvádí, že veškerá tajemství prírody (totius naturae secreta) jsou obsažena ve vyprávění o stvoření světa, jak je popsal Mojžíš, kterému tato tajemství byla zjevena. Mojžíš ovládal veškerou lidskou moudrost. Z Mojžíše pak čerpal Šalamoun, který sepsal nedochovanou knihu Sapientia, jež měla obsahovat veškerou moudrost. ${ }^{i i}$

Přirozeně že i pro Pika se moudrost s nárokem na univerzálnost musela shodovat s křestanstvím. Podle Pika kabalistické knihy obsahují „spíše náboženství křestáanské než mojžíšské“ a „pokud se týká jejich filosofického obsahu, člověk by téměř myslel, že čte Pythagoru nebo Platóna, jejichž učení jsou tak blízká křestanské viřre, že náš Augustin (Confessiones VII,9, pozn. D. Š.) vyjadřuje Bohu svou hlubokou vděčnost za to, že se spisy

i P. Crinitus, Disputatio inter ... Savonarolam et Picum Mirandolam (= De honesti disciplina III,2, Lyon 1554), in: Mirandola 1942, s. 81 n: „Hermes enim, qui Aegyptiis floruit, et qui maximus philosophus, maximus sacerdos et maximus rex fuit, certe cum Mose ipso consentit, eiusque opinioni magnopere accedit. Nam et Pythagorae divina illa philosophia, quam Magicem noncuparunt, magna ex parte ad Mosis disciplinas pertinebat: ut qui ad Hebraeos quoque eorumque doctrinas in Aegyptum usque perrexit, pluraque illorum sacra atque mysteria intellexerit. Nam Platonis etiam eruditio (ut constat) ad Hebraicam veritatem fere accedit; ex quo permulti eum germanum Mosem dixerunt, sed graece loquentem." Srov. s. 170-172. Literárními zdroji těchto údajů o předávání moudrosti byli novoplatonikové a Eusébios; srov. Garinův poznámkový aparát $\mathrm{v}$ uvedené edici a také komentár̆ Blackův, Black 2006, s. 145; srov též Walker 1972, s. 50.

ii Mirandola 1942, s. 170: „[Moses]...deo plenus ac caelesti dictante spiritu totius magistro veritatis, excepit, nonne eumdem nobis cum nostrorum, tum suorum, tum gentium denique testimonia prorsus humanae sapientiae doctrinarumque omnium et litterarum consultissimum prodiderunt?" 
platoniků dostaly do jeho rukou. “' Podobně i v rozpravě se Savonarolou vyjádřil Pico přesvědčení, že se mu podaří dokázat, že křest'anské náboženství se shoduje sprastarou filosofií. Souhlas se týká zejména myšlenek, které obsahuje každé náboženství: že Bůh je věčný a dokonalý a že duše je nesmrtelná."

d) Zastánci ideálu prisca sapientia se dále shodovali v názoru, že dějiny nejsou kontingentní. Nad procesem předávání pravdy stále bdí bohové anebo prožretelnost. Nejpatrnější je tato důvěra v providenci u Ficina, který spatřoval zásah prozřetelnosti téměř ve všech událostech, jež se kolem něj odehrávaly. A díky tomu mohl legitimizovat vlastní program: prastará moudrost se mohla zrodit jen díky tomu, že to chtěla prozřetelnost. iii Vzhledem k tomu, že prozřetelnost ustavičně pečuje o svaté náboženství, řídí i průběh dějin vědění, které obsahuje pravdu tohoto náboženství. V předmluvě ke svým překladům Platónových spisů Ficino dokonce naznačuje, že Boží prozřetelnost opatřila křestáanství platonismem kvưli tomu, aby jakožto vyšší a intelektuálnější forma zbožnosti pomohl udržet mezi věřícími i vzdělance (omnes sapientiae et eloquentiae professores). ${ }^{i v} \mathrm{~A}$ byla to také prozřetelnost, která nedávno vynesla starou moudrost znovu na světlo. ${ }^{\vee} V$ předmluvě k překladu Plotínových spisů Ficino prohlašuje, že božská prozřetelnost ustanovila, aby se spolu se znovuzrozením Platónovy

\footnotetext{
i Mirandola 2005, s. 113. Téměř stejně Mirandola 1969, s. 123: religionem non tam Mosaicam quam Christianam.

ii Crinitus, Disputatio inter Savonarolam et Picum Mirandolam (= De honesti disciplina III,2), in Mirandola 1942, s. 81: „...puto me posteris etiam probaturum Christi religionem magna ex parte cum veteri philosophia consentire..."

iii Ficino 1596, s. 871: „Itaque non absque diuina prouidentia volente ... factum est, ut pia quaedam philosophia ... nasceretur.“

iv Ficino 1596, s. 1128.

v Ficino 1596, s. 1130, srov. 1537.
} 
filosofie (v podobě dokončeného překladu - 1463) zrodil pod hvězdami přejícími mudrcům Pico della Mirandola.' Celý proces obnovování platonismu $v$ podobě překladů a komentářů je tak veden božskou prožretelností. i" A božská prozřetelnost také stanovila pravý úkol obnovené prastaré moudrosti. Právě platónská filosofie, jakožto vrcholná podoba starého vědění, má navrátit bezbožníky k prapůvodnímu spojení moudrosti a náboženstviiii a také kideálu filosofa-krále, který pro Ficina ztělesňuje Lorenzo Medicejský, jak je patrné z předmluvy k Platónské teologii. iv

Ficino sám se pokládal za nástroj prozřetelnosti, který povolán k tomu, aby opětovně sjednotil moudrost s náboženstvím, aby realizoval platónský ideál filosofa-kněze a aby napomohl uskutečnění ideálu filosofa-krále. Považoval za svůj úkol napomoci svou filosofickou činností obnově křestanství, které je ohroženo pověrou, povrchností a ateismem radikálních aristoteliků. Boží prozřetelnosti se zachtělo právě $v$ těchto dobách potvrdit náboženství pomocí filosofie, dokud ve stanovený čas nebude pravé náboženství potvrzeno zázraky. ${ }^{v}$

i Ficino 1596, s. 1537: „Divinitus profecto videtur effectum, ut dum Plato, quasi renasceretur, natus Picus heros sub Saturno Aquarium possidente..." K astrologickému chápání funkce Saturnu v životě filosofa viz například klasickou práci R. Klibansky - E. Panofsky - F. Saxl 1992, s. 351-394.

ii Ficino 1596, s. 1537: „Divina igitur providentiae ducti divinum Platonem \& magnum Plotinum interpretati sumus. “ Srov. Ficino 1596, s. 871.

iii Ficino 2001-2006, Prohemium, vol. I, s. 11.

iv Ficino 2001-2006, Prohemium, vol. I, s. 13,: „...philosophiam una cum summa in rebus publicis autoritate coniunxeris“"

v Ficino 1596, s. 872. Srov. Kristeller 1972, s. 16 n. 
V

Myšlenkový svět renesančního platonismu neobsahoval klíčovou myšlenku moderního pokrokářského smýšlení. Pravda v něm není dcerou času, čas není podmínkou poznání. Pravda byla předána lidem na počátku dějin, $\mathrm{i}$ když mnohdy zůstala tajemně zahalená. $Z$ hlediska této koncepce dějin vědění je pravda jednou provždy daný obsah, který nepřibývá ani neubývá, který nezačíná ani nekončí, který se jen více nebo méně zdařile přenáší v dějinách.' Mudrcové za sebou následují v čase a předávají si prastarou moudrost. Starší je učitelem mladšího, který vždy staví na zděděné tradici nebo si ji přizpůsobuje, ale nikdy ji nepřekonává ani nenahrazuje. Vědění minulosti tak není souborem předsudků, který je třeba odvrhnout jako zátěž bránící dalšímu pokroku. Tak bude uvažovat až osvícenství.

Pro renesanční platoniky je pravda jednou provždy daná, mění se ovšem počet lidí, kteří jsou osvíceni jejím světlem. Dějiny vědění tak získávají poněkud misijní nádech šíření pravého poznání. Nejedná se ovšem o kontinuální proces, nýbrž o sled cyklů, $v$ nichž se stř́idají osvícené doby $\mathrm{s}$ obdobími, kdy je pravé vědění zapomenuto a prekryto barbarskou moudrostí a lidovou pověrou. Renesanční platonici byli nejspíše přesvědčeni, že se právě nacházejí ve vzestupné fázi, kdy dojde prostřednictvím znovuobjevené prisca sapientia $\mathrm{k}$ obrodě a záchraně kultury před škodlivými vlivy a muslimskými nepráteli. Současně si ale museli být vědomi úskalí každého cyklického pojetí dějin: po každém období vzestupu nutně prijide opět úpadek. Je ovšem možné, že $v$ souvislosti $s$ vypjatými eschatologickými představami, které se začaly širíit na přelomu

i Ficino 2001-2006, II,5, vol. I, s. 116-118. 


\section{AIOIIP 7./2013}

15. a 16. století (a ve Florencii je ztělesňoval Savonarola), renesanční učenci soudili, že se jedná o poslední kulturní vzepětí před posledním soudem.

Dalším důvodem pro absenci pokrokářské mentality $v$ renesančním platonismu bylo takové pojetí vědění, které nepředpokládalo, že k získání poznání je třeba čas. Renesanční platonici totiž vycházeli z optimistické noetiky založené na antropocentrické antropologii. Podle Pléthóna by nám bohové nedali touhu po poznání, kdyby nechtěli, abychom poznávali svět. Jsme vybaveni a uzpůsobeni nejen $\mathrm{k}$ tomu, abychom mohli poznat př́rodu, ale také se svým rozumem a jinými schopnostmi duše podobáme bohům, a proto můžeme zkoumat i jejich přirozenost. ${ }^{i}$ Podobně i podle Ficina byla člověku dána přirozená touha po vědění (naturale desiderium), která neustane, dokud nedosáhne svého cíle. A tím je poznání Boha. Sjednocení a splynutí s Bohem je konečný cíl lidské existence a také definitivní ukončení přirozené touhy po vědění.i $K$ tomu Ficino dodává, že jedním ze znaků dobře uspořádaného řádu stvoření je to, že všechny druhy jsou schopny dosáhnout jim vyměřeného cíle. iii Touha po vědění tedy člověku nebyla dána nadarmo a existuje naděje, že může být naplněna. $S$ odvoláním na Origéna Ficino výslovně uvádí, že touhu po poznání jsme od Boha dostali kvůli tomu, aby byla jednou uspokojena, nikoli aby ji do nás vložil nadarmo. ${ }^{\text {v }}$ Bůh se nechává poznat skrze př́rodu, která $v$ padlé duši

i Pléthón 1858, I,3, s. 40-42.

ii Ficino 2001-2006, XIV,2, vol. IV, s. 226-228: „.Quare in sola dei sive cognitione sive possesione ultimus finis consistit humanus, quae naturalem sola terminat appetitum.“

iii Ficino 2001-2006, XIV, 2, vol. IV, s. 232.

iv Ficino 2001-2006, XIV,2, vol. IV, s. 238: „...nos conditione a deo eiusmodi desiderium accepisse, qua aliquando posset expleri, ne frustra a deo sit insitum.“ 
postupně probouzí vrozená rozumová určení (rationes) věcí. ${ }^{i}$ To znamená, že svět je otevřen lidské touze po poznání. Nabízí se přirozeně lidským poznávacím schopnostem. Existuje předzjednaná teleologie mezi lidskými poznávacími schopnostmi, empirickou prrírodou a duchovním světem.

Proti tomu novověká idea pokroku je postavena na myšlence nuceného odkladu. Podle novověkých autorů příroda není teleologicky uzpůsobená pro lidské potřeby. Odmítá se nechat poznat a vzpírá se člověku. Zvláště protestantští autoři, jako byl třeba Bacon, považovali ze důsledek pádu člověka neochotu prírody podřídit se lidské touze po vědění a moci. ii $Z$ toho pak plynula nutnost nasazení „umělých“, „invazivních“ metod, které dosud prrírodní filosofie neznala. Bylo třeba vymámit na prírodě její tajemství pomocí experimentálních postupů. A jejich vyhodnocení si vyžadovalo čas a dlouhodobou, mezigenerační spolupráci vědců.

S tímto rozdílem v chápání naděje na uspokojení lidské touhy po poznání souvisí i další důvod pro absenci myšlenky teoretického pokroku. Pro renesanční platoniky není pravda vlastnost soudů, ale pravda je především zážitek, světlo (lux dei aeterna). iii Jeho intenzita závisí na stavu duše, která je prijímá. Jedná se tedy o morální pojetí vědění, podle něhož musí člověk procházet $v$ průběhu poznávacího procesu somatickými i duchovními proměnami. Musí poznat sám sebe a změnit svůj způsob života - a ještě se mu musí dostat Boží milosti. ${ }^{\text {iv }}$ Podle Ficina člověk vede život rostliny, když při stravování hýčká své tělo. Život zvířete vede, když se opájí svými smysly, život člověka, když se řídí rozumem v lidských záležitostech, život héroa,

i Ficino 1596, s. 1350. Srov. Karfík 2010, s. 53-63.

ii Bacon 1963, vol. III, s. 296; srov. vol. III, s. 222. Srov. Harrison 2007.

iii Viz např́klad Ficino 1596, s. 1351.

iv Viz klasickou práci Hadot 1995, s. 21-64. Srov.Hladký 2010, s. 13-50. 
když studuje prrírodní jevy, život démona, když se zabývá matematickými spekulacemi, život anděla, když zkoumá božská mystéria, a život Boha, pokud dělá všechno kvůli Bohu. Cílem poznávacího úsilí bylo vystoupat vzhůru, odpoutat duši od těla a stoupat pres planetární sféry zpět ke svému původci a skutečnému cíli a pohroužit se do kontemplace. Celé snažení naší duše spočivá $v$ tom, aby se stala Bohem. "i Vědění tedy proměňuje samotného nositele, povznáší ho a zbožštuje. Proti myšlence jiskry zažehnuté božským světlem po morální konverzi stojí ovšem novověký pseudodemokratismus metody, která je přístupná všem bez ohledu na jejich vnitřní uzpůsobení. Všichni jsme od př́rody stejně nadáni světlem přirozeného rozumu. Záleží jen na tom, jestli máme správnou metodu pro jeho užívání, ríká Descartes v prvních větách Rozpravy o metodě. Poznání nemá měnit svého nositele $v$ anděla, jak chtěl Pico della Mirandola. ${ }^{\text {iii }} A$ není dosažitelné v okamžitém záblesku pravdy, ale zdlouhavým a pracným uplatňováním metody.

Nemyslitelnost pokroku $v$ kontextu renesančního platonismu vysvětluje ještě další rys optimistické noetiky založené na teleologii světa. Člověk renesančních platoniků nepotřebuje získat moc nad prírodou. $V$ návaznosti na tradiční hermetickou představu člověka jako druhého Bohav Ficino

i Ficino 2001-2006, XIII,3, vol. IV, s. 240-242: „...Vitam daemonum, prout mathematica speculatur. Vitam angelorum, prout divina inquit mysteria. Vitam dei, quantum dei gratia omnia operatur."

ii Ficino 2001-2006, XIV,1, vol. IV, s. 220: „Totus igitur animae nostrae conatus est, ut deus efficiatur. Conatus talis naturalis est hominibus non minus quam conatus avibus ad volandum; inest enim hominibus omnibus semper ubique. Ideo non contingentem alicuis hominis qualitatem, sed naturam ipsam sequitur speciei.“ iii Viz Copenhaver 2002.

iv Rüfner 1955. 
v Platónské teologii emfaticky popisuje umění a výjimečné schopnosti, které lidem přinášejí panství nad pozemskou přírodou. Člověk svobodně nakládá se všemi pozemskými látkami, s kameny, rostlinami i se zvířaty. Použíaá je všechny, jako by byl jejich pán (utitur omnibus, quasi sit omnium dominus). Člověk je jakoby Bůh panující nad živými a neživými věcmi; je jistě bohem zvířat, která užívá a jim panuje. Je bohem živlů i bohem látek, které mění a utváří. Ale touha a slávychtivost člověka se nevyčerpává panstvím nad pozemským světem. Má ambice podrobit si také nebeský, resp. duchovní svět. Ovšem univerzální panství náleží jen Bohu, a tak člověk usiluje o

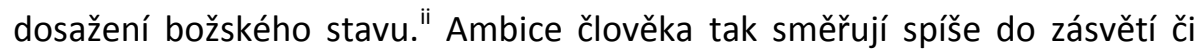
transcendence, nikoli do pozemského světa. Skutečný cíl lidského úsilí leží jinde než na zemi. Možná také kvůli tomu ideál prisca sapientia zůstal v 16. století katolickou záležitostí. ${ }^{\text {iii }}$ Protestantský aktivní a podnikavý přístup k časnému, prírodnímu světu a současně i hluboké přesvědčení o zkaženosti lidské přirozenosti byly vzdáleny napůl pohanskému ideálu vzestupu k Bohu, při němž úloha boží milosti byla sice zmiňována, ale přesto mohl přetrvávat dojem, že se jedná o troufalý pokus, který má poprít důsledky prvního

i Ficino 2001-2006, XIII,3, vol. IV, s. 172-174. „Homo igitur qui universaliter cunctis et viventibus et non viventibus providet est quidam deus. Deus est proculdubio animalium qui utitur omnibus, imperat cunctis, instruit plurima. Duem quoque esse constitit elementorum qui habitat colitque omnia. Deum denique omnium materiarum qui tractat omnes, vertit et format“. Srov. McKnight 1991, s. 42-50.

ii Ficino 2001-2006, XIII,5, vol. IV, s. 250: „Sed quantum pertinet ad victoriae cupiditatem, immensam animi nostri magnificentiam ex hoc manifeste licet perspicere, quod non satis illi futurum sit mundi huius imperium, si hoc subacto alium resciverit superesse mundum, quem nondum suberegit. ... Ita nec superiorem vult homo neque parem, neque patitur superesse aliquid ab imperio eius exculsum. Solius dei hic status est. Statum igitur querit divinum.“ iii Hanegraaff 2006, s. 1129b. 
hř́chu. Protestanti tyto důsledky sice chtěli také napravit, ale nikoli stoupáním člověka $\mathrm{k}$ Bohu, nýbrž tím, že se lidem vrátí moc, kterou disponovali $v$ ráji - a to prostřednictvím empirického a kolektivního zkoumání prírody. Již v roce 1532 napsal německý protestantský teolog Simon Grynaeus (1493-1541) v předmluvě k souboru textů Novus orbis regionum ac insularum veteribus incognitarum, že objevením Ameriky člověk znovu získává imperium terrae et marium, jež náleželo Adamovi v ráji, ale které bylo ztraceno v důsledku prvního hř́chu. Zámořské výpravy představují prostředek, jak zvrátit ztrátu vědění a moci, která postihla prvního člověka. Cestovatelé, ale také kosmografové a matematikové jsou nástroji boží prozřetelnosti při novém podmaňování prírody člověku.' Později uvažoval podobně i Francis Bacon, který oslabil úlohu boží prozřetelnosti, zato však posílil úlohu metody při znovuzískávání vědění, které měl člověk $v$ ráji. Konečným cílem lidského poznávání je návrat k panství, jímž se vyznačoval rajský stav. Není to potěšení zvědavosti (pleasure of curiosity), která je cílem vědění, ale obnovení suverenity a moci, kterou měl člověk v prvním stavu stvoření, tj. v ráji.ii

Snad Ize tedy obecně ríci, že pro renesanční platoniky i pro mnoho jiných renesančních myslitelů si poznání nevyžadovalo čas. Člověk, který je imago Dei, který může stoupat $\mathrm{k}$ Bohu a kterého poslouchá svět prírody, nepotřebuje čas. Dokud je pravda plodem contemplatio Dei a božské inspirace, není třeba předpokládat, že na vědění musíme trpělivě a po generace čekat. Čas začíná vystupovat jako podmínka poznání ve chvíli, kdy

i Grynaeus 1537, fol a2v-a3r.

ii Bacon 1963, sv. III, s. 222: „...it is a restitution and reinvesting (in great part) of man to the sovereignty and power ... which he had in his first state of creation." Srov. sv. III, s. 264, sv. I, s. 132. 
se ukazuje nesoulad mezi poznávacími schopnostmi člověka a nezměrností př́rody. Nejprve k tomu došlo v astronomii, která ukázala, že příliš velká pomalost některých jevů na obloze vede $\mathrm{k}$ jejich nepostižitelnosti během individuálního života. ${ }^{i} \mathrm{~V}$ novověku se vědomí lidské bezvýznamnosti vůči kosmu rozširrilo i do dalších oborů spolu s presvědčením o bezohlednosti prrírody vůči lidské touze po poznání. Novověk nastupuje jako epocha nedostatku a nesouladu, které byly důsledkem odmítnutí antropocentrické teleologie. Změna $v$ pojmu dějin vědění tedy souvisí rovněž se ztrátou účelnosti prírody, jak ve svých pracích zdůrazňoval Hans Blumenberg. ii Ve světě, který je představován jako Ihostejný vůči lidské touze po poznání, se pravda musela stát dcerou času. Současně však pomalost a pracnost metodického objevování pravdy propůjčovala získávání vědění patos autonomie. Lidstvo už za své poznání vděčí pouze samo sobě, nikoli boží milosti ani předem nastavené, přívětivé teleologii. A právě $v$ tom spočívá jeden z klíčových rozdílů mezi renesancí a novověkem.

\section{Bibliografie:}

Bacon, F., 1963, The Works of Francis Bacon, eds. J. Spedding, R. L. Ellis, D. D. Heath, 1857-1874, repr. Stuttgart - Bad Cannstatt, 14 sv.

i Viz podrobněji Špelda 2005.

ii Blumenberg ${ }^{3}$ 1996, 1996, ${ }^{2}$ 1983, 2009. 
Bailly, J.-S., 1777, Lettres sur l'origine des sciences, Paris.

Bailly, J.-S., 1781, Histoire de l'astronomie ancienne, Paris.

Bailly, J.-S., 1785, Histoire de l'astronomie moderne, Paris.

Bessarion, 1927, In Calumniatorem Platonis, Paderborn 1927 (= L. Mohler, Kardinal Bessarion als Theologe, Humanist und Staatsman, Bd. 2).

Black, C., 2006, Pico's Heptalus and Biblical Hermeneutics, Leiden - Boston 2006.

Blum, P. R., 2010, Philosophy of Religion in the Renaissance, Franham Burnligton, s. 95-108.

Blum, P. R., 2011, „,Et nuper Plethon“ - Ficino's Praise of Georgios Gemistos Plethon and His Rational Religion“, in: Clucas, S. - Forshaw, P. J. - Rees V. (eds.), Laus Platonici Philosophi. Marsilio Ficino and his Influence, Leiden - Boston, s. 89-104.

Blumenberg, H., ${ }^{2} 1983$, Die Lesbarkeit der Welt, Frankfurt a. M.

Blumenberg, H., 1986, „Wahrheit, Tochter der Zeit?“ in týž, Lebenszeit und Weltzeit, Suhrkamp, Frankfurt a. M., s. 153-172.

Blumenberg, H., 1996, Die Legitimität der Neuzeit. Erneuerte Ausgabe, Frankfurt a. M.

Blumenberg, H., 2009, Geistesgeschichte der Technik, Frankfurt a. M. 
Blumenberg, H., ${ }^{3} 1996$, Die Genesis der kopernikanischen Welt, Frankfurt a. M.

Burns, D., 2006, „The Chaldean Oracles of Zoroaster, Hekates's Couch, and Platonic Orientalism in Psellos and Plethon“, Aries 6, s. 158-179.

Copenhaver, B., 2002, „The Secrets of Pico's Oration: Cabala and Renaissance Philosophy“, Midwest Studies in Philosophy 26, s. 56-82.

Dannefeldt, K. H., 1952, „The Renaissance and the Pre-Classical Civilizations", Journal of the History of Ideas 13, s. 435-449

Dodds, E. R., 1973, The Ancient Concept of Progress, Oxford.

Ebert, H., 1929, 1930, "Augustin Steuchus und seine Philosohia perennis", Philosophisches Jahrbuch 42, s. 342-356, 510-526; 43, s. 92-100.

Edelheit, A., 2008, Ficino, Pico and Savonarola. The Evolution of Humanist Theology, 1461-1498, Leiden - Boston.

Edelstein, L., 1967, The Idea of Progress in Classical Antiquity, The Johns Hopkins Press, Baltimore, s. 105-132.

Euler, W. A., 1996, „Pia Philosophia“ et „docta religio“. Theologie und Religion bei Marsilio Ficino und Giovanni Pico della Mirandola, München.

Farmer, S. A., 1998, Syncretism in the West: Pico's 900 Theses, Tempe.

Ficino, M., 1576, Opera, Basileae. 
Ficino, M., 2001-2006, Platonic Theology, ed. J. Haskins, The Tatti I Library Harvard University Press, Cambridge, Mass. - London, 6 sv.

Findlen, P., 2002, "Historical Thought in the Renaissance“, in: Kramer, L. Maza, S. (eds.), A Blackwell Companion to Western Historical Thought, Oxford, s. 99-119.

Garin, E., 2008, History of Italian Philosophy, 2 vols, Amsterdam - New York.

Gentile, G., 1920, „Veritas filia temporis“, in: Gentile, G., Giordano Bruno e il pensiero del Rinascimento, Firenze, s. 89-110.

Gren, Fr. A. C., 1799, „Geschichte der Naturwissenschaft, als akademische Vorlesungen vorgetragen. Ein Fragment aus dessen nachgelassenen Papieren“, Annalen der Physik 1, s. 167-204.

Grynaeus, S., 1537, Novus orbis regionum ac insularum veteribus incognitarum, Basileae.

Hadot, P., 1995, Philosophy as a Way of Life. Spiritual Exercises from Socrates to Foucault, Oxford.

Hadot, P., 2010, Isidin závoj. Esej o dějinách ideje přírody, Praha, s. 163-177

Hanegraaff, W. J., 2006, „Tradition - Prisca Theologia and Philosophia Perennis", in: Hanegraaff, W. J. (ed.), Dictionary of Gnosis and Western Esotericism, Leiden - Boston, s. 1125-1135.

Hanegraaff, W. J., 2009, „The Pagan Who Came from the East: George Gemistos Plethon and Platonic Orientalism“, in: W. J. Hanegraaff - J. 
Pijnenburg (eds.), Hermes in the Academy. Ten Years' Study of Western Esotericism at the University of Amsterdam, Amsterdam.

Hankins, J., ${ }^{2}$ 1991, Plato in the Italian Renaissance, Leiden - New York Köln.

Harrison, P., 2007, The Fall of Man and the Foundations of Science, Cambridge.

Havrda, M., 2009, „Víra, symbol, poznání. Pátá kniha Stromat v rámci Klementova filosofického projektu“, in: Klement Alexandrijský, Stromata V, přel. M. Havrda, Praha.

Hladký, V., 2009, „B. Tambrun-Krasker on George Gemistos Plethon“, Byzantinoslavica 67, s. 372-380.

Hladký, V., 2010, Plato's Second Coming. An Outline of the Philosophy of George Gemistos Plethon, disertační práce FF UK, Praha (v tisku).

Hladký, V., 2010, Změnit sám sebe. Duchovní cvičení Pierra Hadota, péče o sebe Michela Foucaulta a péče o duši Jana Patočky, Praha.

Hoffmann, T. S., 2007, Philosophie in Italien, Hamburg.

Chadwick, H., 1966, repr. 2002, Early Christian Thought and the Classical Tradition. Studies in Justin Clement, and Origen, Oxford.

Chlup, R., 2007, Corpus Hermeticum, Praha. 
Karfík, F., „Ficinova teorie poznání v De amore“, in: Jabůrek, M. Nejeschleba, T. (eds.), Proměny vědění od Augustina $k$ dnešku, CDK, Brno 2010, s. 53-63.

Klement Alexandrijský, 2009, Stromata V, přel. M. Havrda, Praha.

Klibansky, R. -Panofsky, E. -Saxl, F., 1992, Saturn und Melancholie. Studien zur Geschichte der Naturphilosophie und Medizin der Religion und der Kunst, Frankfurt a. M.

Kristeller, P. O., 1972, Die Philosophie des Marsilio Ficino, Frankfurt a. M.

Laplace, P.-S., 1884, Exposition du système du monde, Livre V: Précis de I'histoire de l'astronomie, in: Laplace, P.-S., Oeuvres complètes, sv. VI, Paris.

Malusa, L., 1993, „Renaissance Antecedents to the Historiography of Philosophy“, in: Santinello, G. (ed.), Models of the History of Philosophy, vol. I: From Its Origins in the Renaissance to the ,Historia philosophica', Dordrecht - Boston - London.

Martin, J. E., 2000, Cardinal Bessarion, Mystical Theology and Spiritual Union between East and West, PhD. thesis, University of Manitoba.

McKnight, S. A., 1991, The Modern Age and the Recovery of Ancient Wisdom, University of Missouri Press, Columbia - London.

Mommsen, T. E., 1942, „Petrarch's Conception of the ,Dark Ages“", Speculum 17, s. 226-242. 
Nejeschleba, T., 2004, „Mýtus mága Zoroastera v renesanci“, in: Nechutová, J., Druhý život antického mýtu, Brno, s. 153-162.

Nejeschleba, T., 2008, Jan Jessenius v kontextu renesanční filosofie, Praha.

Panofsky, E., 1962, „Father Time“, in: Panofsky, E., Studies in Iconology, New York ${ }^{2} 1962$, s. 63-93.

Perrault, M., 1693, Paralelle des anciens et des modernes, Paris.

Pico della Mirandola, 1557, repr. 1969, Opera omnia, Basileae, repr. Hildesheim.

Pico della Mirandola, 1942, Heptaplus, in: Pico della Mirandola, De hominis dignitate, Heptaplus, De ente et Uno, ed. E. Garin, Firenze.

Pico della Mirandola, 2005, O důstojnosti člověka / De dignitate hominis, přel. D. Sanetrník, Praha.

Pléthón, 1858, Traité des lois, ed. C. Alexandre, trad. A. Pellissier, Paris.

Pléthon, 1995, Magika logika. Oracles Chaldaïques. Recension de Georges Gémiste Pléthon, Athens - Paris - Bruxelles.

Proklos, 1968, Théologie platonicienne, Livre I, eds. H. D. Saffery - L. G. Westenrink, Belles Lettres, Paris.

Recension de Georges Gémiste Pléthon, 1995, ed. B. Tambrun-Krasker, Athens - Paris - Bruxelles. 
Rüfner, V., 1955, „Homo secundus deus. Eine geistesgeschichtliche Studie zum menschlichen Schöpfertum", Philosophisches Jahrbuch 63, s. 248291.

Saxl, F., 1963, "Veritas filia temporis“, in: Klibansky, R. - Paton, H. J. (eds.), Philosophy and History, New York - London, s. 197-223.

Schmidt-Biggemann, W., 2004, Philosophia Perennis. Historical Outlines of Western Spirituality in Ancient, Medieval and Early Modern Thought, Dordrecht, s. 428-434.

Schmitt, C. B., 1966, „Perennial Philosophy: From Agostino Steuco to Leibniz", Journal of the History of Ideas 27, s. 505-532

Stuckrad, K. von, 2010, Locations of Knowledge in Medieval and Early Modern Europe, Leiden - Boston, s. 25-31.

Špelda, D., 2005, „Astronomie a idea teoretického pokroku, Aluze. Revue pro literaturu, filosofii a jiné 3/2005, s. 124-145.

Tambrun, B., 2006, Pléthon. Le retour de Platon, Paris.

Turgot, A.-R.-J., 1913, Causes du progrés et de la décadence, in: Turgot, A.R.-J., Ouvres, tom. I., ed. G. Schelle, Paris.

Walker, D. P., 1972, The Ancient Theology. Studies in Christian Platonism from the Fifteenth to the Eighteenth Century, London.

Woodhouse, C. M., 1986, George Gemistos Plethon. The Last of the Hellenes, Oxford. 
Zhmud, L., 2006, The Origins of the History of Science in Classical Antiquity, Berlin - New York.

Zittel, C., 2002, „,'Truth is the daughter of time'. Zum Verhältnis von Theorie der Wissenschaften, Wissensideal, Methode und Wissensordnung bei Bacon", in: Detel, W. -Zittel, C. (eds.), Wissensideale und Wissenskulturen in der frühen Neuzeit, Berlin, s. 213-238. 